\title{
Introduction: Bilingualism, Multilingualism and the Formation of Europe
}

\author{
Jan Bloemendal
}

If we were to exaggerate slightly, we might state that the formation of European national cultures starts and ends with a treatise in Latin in praise of the vernacular, viz. Dante's De vulgari eloquentia ('On the Vernacular', ca. 1300), the first manifest example of a work about the use of the vernacular, and Jacob Grimm's inaugural lecture at Göttingen, De desiderio patriae ('On the Longing for the Homeland', 1830). ${ }^{1}$ Both treatises advocated a new ideology of national identity based on the mother tongue, expressed in Latin. Within the polyglot world of Europe the international Latin was not merely a language, but the carrier of European culture par excellence, conveying common values and beliefs. If research into the questione della lingua (a dispute in the Cinquecento on the language to be used in Italy, viz. Latin or the vernacular) has treated Latin and the vernacular languages as conflicting opposites representing a world in transition from a culture based mainly on Latin to a culture expressed mainly in the vernacular languages, the examples of Dante and Grimm qualify this, as well as the vast number of Latin poems, for instance, written after the battle of Jena and Auerstedt as late as $1806 .^{2}$ In the Hungarian Parliament Latin was used from 1825 when it first reconvened until the year of revolution 1848 in order to avoid affording linguistic hegemony to one of the languages in the nation. Latin is the official language of the Roman Catholic Church even to the present day. When Pope Benedict XVI announced his abdication on 11 February 2013, he did so in a Latin 'tweet' of 140 characters. The only Vatican journalist who knew Latin, Giovanna Chirri, had the scoop. ${ }^{3}$ His official speech of abdication was also in this language.

The traditional account of history fixed the downfall of Latin as a world language (presumed 'elitist') in the seventeenth century, with the demotic idioms (presumed 'egalitarian') taking over as part of what is usually described

1 See Leerssen, National Thought in Europe, p. 54 on Dante, and pp. 146-47 on Grimm. See for Latin and national identities also: Coroleu, Caruso and Laird, The Role of Latin in the Early Modern World.

2 Presented by Hermann Krüssel at the 15th congress of the International Association for Neo-Latin Studies, Münster 2012.

3 See Butterfield, 'Latin and the Social Media', p. 1015. 
as the emergence of the nation states. However, there is a growing awareness that Latin and the vernacular did not take turns representing an old and new Europe, but rather coexisted together for centuries in overlapping and mutually influential communities. Interest in the intersection between Latin and the vernaculars and its dynamics has increased during the last decade, witness, for instance, some issues of the journal Renaessanceforum, the study by Nikolaus Thurn on 'Neo-Latin and the Vernaculars', the work of the Centre for Renaissance Studies in Warwick and the project Dynamics of Latin and the Vernacular at the Huygens Institute in The Hague, and Amsterdam and Nijmegen. ${ }^{4}$ In particular, the cultures of translation have been studied and reflected upon. ${ }^{5}$ Whereas previous investigations were carried out in a more comparative way, nowadays a more dynamic view of Latin and vernacular cultures prevails.

One study deserves special mention. In chapters two and three of his informative study on languages and communities in early modern Europe, Peter Burke discusses the place of Latin in Europe's linguistic spectre. Chapter two, 'Latin: A Language in Search of a Community', states that by the ninth century no native speakers of Latin existed any more. Latin 'sought' speech communities and found them in the Roman Catholic Church, where it was the liturgical language for ages, and in the international respublica literaria and other inter- or supra-national communities, where it became the lingua franca of literates, lawyers, diplomats, scientists and many more. Latin and the vernaculars coexisted and provided an example of 'diglossia', 'in the sense that it was considered appropriate to use in some situations and domains. ${ }^{6}$ In the next chapter, 'Vernaculars in Competition', Burke discusses the emancipation of the vernacular languages at the expense of Latin. This is only partly true, he states, viz. for the increase of vernacular printing. However, for a long time Latin kept its position as international language. Burke suggests a comparative approach, which is highly informative. The present volume, however, takes a further step in its approach in terms of dynamics of languages and mutual exchange, although both studies resemble one another in their sociolinguistic approach. ${ }^{7}$

4 Coroleu, Caruso and Laird (eds.), The Role of Latin in the Early Modern World; Hass and Ramminger (eds.), Latin and the Vernaculars in Early Modern Europe; Thurn, Neulatein und Volkssprachen. See also Ford's study The Judgment of Palaemon, on the use of Latin or French in Renaissance poetry in France.

5 See, for instance, Burke, Lost (and Found) in Translation and Burke and Po-chia Hsia, Cultural Translation in Early Modern Europe.

6 Burke, Languages and Communities in Early Modern Europe, p. 43.

7 See also Deneire, 'Chapter 22: 'Neo-Latin and the Vernacular: Methodological Issues'. 
In this volume crossroads between Europe's Latin and vernacular cultures are explored, and their points of convergence and divergence identified. These questions were the starting point: To what extent did the language systems and the windows of cultural references open up as a result of social interactions within the communities and political, religious and educational institutions of early modern Europe? What was the impact of bilingualism or 'diglossia' on social stratification and the self-fashioning and self-presentation of individuals or groups? ${ }^{8}$ And what were the implications of the fact that a considerable number of authors, including Dante, Petrarch, Thomas More, Martin Luther and Hugo Grotius, published both in Latin and in the vernacular?

To some extent, these questions may themselves be questioned. We tend to speak of 'bilingualism' or 'diglossia', to indicate that an author had the choice to write in Latin or in the vernacular. However, the terms vernacular and Latin have to be qualified. 'The' vernacular consists of many languages and dialects, and even sociolects and idiolects, and people may speak and write, or at least understand, more than one of them. Someone in Germany could choose between the use of 'Alemannic', 'Hochdeutsch' (when that had come into existence), or a local dialect, for instance. The same is true for Dutch, where the Brabantic and Hollandic dialects, to name two of them had much in common, but also differed considerably. Even the dialects of the Low Countries and the German lands were considered to be akin to the extent that 'Dutch' dialects were considered dialects of 'German'. The dialect of the Rhineland stretched from Germany to the southern parts of the Netherlands. The dialects spoken along the Rhine, from Basel to Rotterdam, were, certainly in the fifteenth and sixteenth centuries, not considered as different languages, such as 'Alemannic', 'Deutsch' or 'Dutch'.

For the Latin part, too, we should speak of Latin languages in the plural as Françoise Waquet suggests in her contribution, since the mastery of Latin varied so widely at the universities, ranging from men who knew Latin as well as their mother tongue, to those who only knew enough Latin for their particular purpose. Yet, one could choose. Immanuel Kant, for instance, wrote his doctoral thesis and his Habilitationsschrift in Latin, Meditationum quarundam de igne

8 Self-fashioning is understood as the image someone conceives of himself by what he communicates about his own person, combined with what others communicate about him and the cultural and social conventions, which takes place more on a subconscious level, and selfpresentation as a deliberate attempt to have others conceive a particular image of oneself. See Deneire, 'Neo-Latin and Vernacular Poetics of Self-Fashioning'. For more information, see Pieters and Rogiest, 'Self-fashioning in de vroeg-moderne literatuur- en cultuurgeschiedenis', and Geerdink, “'Self-fashioning” of zelfrepresentatie?' 
succincta delineatio ('Short Outline of SomeThoughts on Fire') and Principiorum primorum cognitionis metaphysicae nova dilucidatio ('New Light on the First Principles of Metaphysical Knowledge') respectively (both in 1755!), and then turned to German..$^{9}$ At the same time, when he coined a technical philosophical vocabulary for the German language, he made use of Latin. In this respect, he did exactly the same as Cicero had done in Rome in the first century вС, when the latter created a set of philosophical terms for Latin by using Greek, either transcribing Greek terms, or translating them from Greek into Latin, thus forming neologisms like qualitas, quality, and inventing 'the Western World's philosophical vocabulary'. ${ }^{10}$

We also have to bear in mind that Latin started as a vernacular language in Rome and Latium. Even in classical times, there was no 'one' Latin, as can be induced from this sentence: 'Latinitas est incorrupte loquendi observatio secundum Romanam linguam' ('right Latin is the faultless use of the language according to the accent in Rome')." The questione della lingua found its origins in a discussion on the several 'levels' of Latin, viz. literary versus colloquial language. That language conquered the world and became the mother tongue of many more people, even though in the eastern part of the Empire Greek remained the language used. In the Middle Ages Latin became more and more the people's 'second' language, for which the term Vatersprache ('father tongue') was formed. However, it remained a language that could be used and had to be adapted to new needs. For instance, feeling the need for new words for new concepts, the scholastic philosophers coined them with the use of principles with which they were familiar (for instance, adding -(i)tas to a word to form an abstract word, cf. the English -(i)ty), such as the word quidditas, 'quiddity', 'essence'.

The same applies to the early modern period. Neologisms were coined and used. A famous example is the title of Thomas More's vision of an ideal state Utopia ('Nowhere-Place'), but many others can be indicated. Other Latin words were loaded with new meanings. Both phenomena can be amply seen in Hoven's Dictionary of Renaissance Latin. ${ }^{12}$

9 Kant, AA, I: Vorkritische Schriften I, 1747-1756, pp. 369-384 and 385-416. See also the contribution by Wiep van Bunge in this volume.

$10 \quad$ McKendrik, The Roman Mind at Work, p. 64.

11 Fr. 268 Funaioli.

12 Hoven, Grailet, transl. by Coen Maas, Lexique de la prose latine de la Renaissance / Dictionary of Renaissance Latin from Prose Sources. See also Helander, 'Ch. 3: On Neologisms in Neo-Latin'. 
The relationship between Latin and vernacular languages changed over time, 'from rivalry to cross-fertilization, from an agenda of defence of Latinor matter-of-fact statements of the superiority of the Latin language-and newly found assertiveness of the vernaculars to concerted bilingual or multilingual strategies of propaganda and outreach.13 In the Quattrocento, for instance, Italian humanists felt the need for a theoretical framework and a vocabulary for the relationship between Latin and the volgare. ${ }^{14}$ As a matter of fact, it mattered whether one spoke of lingua vulgaris ('language belonging to the mob', with the connotation of a low status) or lingua vernacula ('indigenous language', with the connotation of authenticity). ${ }^{15}$

The relationship between Latin and vernacular languages shifted over time, but differed for each geographic region, 'due to the asynchronous spread of Latin humanist culture. ${ }^{16}$ Thurn already pointed to the character of neo-Latin literature as both international and regionalist. ${ }^{17}$ Mutatis mutandis, the same applies for the formation of 'nation states' with some kind of 'national' language. This is also a phenomenon that might differ for each region or country. In France, a 'nation' was formed at an early stage, as was the case in England. But in Italy and Germany the several small states became a union in the nineteenth century, in the process of Risorgimento between 1815 and the 1870 s and the unification of 1871 to form a German Empire respectively. This also affected the relationship between Latin and the vernacular. However, the questions of how and to what extent require further investigation. The compilation of early modern dictionaries of Latin-vernaculars and vice versa can also been seen in the light of the assessment of the balance between Latin and other languages. ${ }^{18}$

The balance between the use of Latin and the vernaculars may also differ for each branch of knowledge. As Wiep van Bunge shows in his contribution, in philosophy Latin was substituted by vernaculars in the eighteenth century, whereas in his chapter Floris Cohen attributes this shift mainly to the use of 'old', authority-based science versus 'new', experimental science in the same period. However, for the university in general this need not to be so, as proved by Françoise Waquet, who demonstrates that the universities throughout the

\footnotetext{
13 Hass and Ramminger, 'Preface', p. ii.

14 Ibidem.

15 See Ramminger, 'Humanists and the Vernaculars'.

16 Hass and Ramminger, 'Preface', p. ii.

17 Turn, Neulatein und Volkssprachen; id., 'Chapter 23: Neo-Latin and the Verncular: Poetry'. See also my adaptation of Thurn's methodological questionnaire, 'Dynamics of Neo-Latin and the Vernacular: Some Thoughts Regarding Its Approach'.

18 See Considine, Dictionaries of Early Modern Europe.
} 
eighteenth century kept feeling the need for a distinctive language that could be labelled 'elitist'. More research on the 'death of Latin' needs to be carried out to establish whether, how and why these differences in view applied.

In the early modern period, many authors spoke and wrote their treatises and poetry both in Latin and in the vernacular, even though there are differences. The 'father of Northern humanism' Desiderius Erasmus (1466-1536), for instance, spoke far more Latin than Dutch. Allegedly he spoke Dutch-or Alemannic — on his deathbed, saying: 'Liever Gott'. ${ }^{19}$ However, in his works he used numerous proverbs, a considerable number of them originating in the vernaculars, viz. Dutch or one of the German dialects, as Ari Wesseling has shown. ${ }^{20}$ Other authors, too, were 'bilingual' or even 'multilingual' in their writings. The 'arch-humanist' Francesco Petrarch (1304-1374) wrote some works in Latin and others in the 'volgare', ranging from an epic in Latin, Africa, to Italian poetry in his Canzoniere. A few other instances among many are the Dutch humanists such as Daniel Heinsius (1580-1655) and Hugo Grotius (1583-1645), who wrote poetry in Latin and in Greek, and even transposed some of their own Latin writings into the vernacular, ${ }^{21}$ whereas Constantijn Huygens (1596-1687), diplomat and secretary to the Stadtholders of the House of Orange, wrote verses in several languages including Latin, Dutch, French and Italian. As much as two centuries later the French poet Arthur Rimbaud (1854-1891) still wrote Latin poems during his education. Part of this 'bilingualism' is closely connected to the humanists' wish to emancipate literature in the vernacular through imitation of classical and humanist poetics. With their

19 See, for instance, Van der Blom, 'Die letzten Worte des Erasmus', who quotes the source, the preface by Beatus Rhenanus to Erasmus's posthumously printed edition of Origin: '[...] assidue clamans: "O Iesu, misericordia, Domine, libera me, Domine, fac finem, Domine, miserere mei”, et Germanica lingua "Lieuer Gott", hoc est "Chare Deus"'. ('[...] constantly shouting: "O Jesus, have mercy, Lord, redeem me, Lord, bring the end, Lord, have mercy upon me": and in Dutch/German: "Liever God", that is "Dear God"'. He could have spoken both Dutch, 'Lieve God', or Alemannic, 'Liebe Gott' or German: 'Lieber Gott'. The term 'Germanica lingua' can indicate both Dutch (or one of its dialects) and German; Dutch was by then considered a dialect of German or Alemannic.

20 However, the evidence compiled by Ari Wesseling in 'Are the Dutch Uncivilized?, 'Dutch Proverbs and Ancient Sources in Erasmus' Praise of Folly', 'Dutch Proverbs and Expressions in Erasmus' Adages, Colloquies and Letters', and 'Intertextual Play: Erasmus' Use of Adages in the Colloquies', is convincing enough to think primarily of Dutch, and only in the second instance of the German dialects or Alemannic.

21 Grotius, Bewijs van de Ware Godsdienst / De veritate; Heinsius, 'Dulcis puella', see Deneire, 'Heinsius, Opitz and Vernacular Self-translation'. 
poetry and prose, these authors also contributed to the 'formation of Europe' as a whole and of its several countries.

The choice of language could be made on the basis of convention. Some genres were written in Latin, others in vernacular languages. Anyone writing an epic would tend to write it in Latin, for instance. In the speculative sciences works were likely to be written in Latin, whereas works on empirical investigations were often written in the vernacular. Choices could be made deliberately, as the case of René Descartes shows. ${ }^{22}$ However, the choice of language is not necessarily implying an 'elitist' audience for Latin versus a 'common' readership for the vernacular.

Another significant issue is typography. In most of Northern Europe, different typefaces were often used when printing Latin and the vernacular: Roman fonts for Latin and Gothic ones for the vernaculars (the development of the vernaculars is related to printing). Approximately the same holds for manuscripts, where different hands were applied. Latin was mostly written in the humanist minuscule that became a model for the roman typeface.

We speak about bilingual and multilingual Europe. In this context, we have to bear in mind that in early modern times, on the Continent only very few scholars could read English. However, in other cases, too, the knowledge of languages other than Latin and the mother tongue was scarce and frequently scholars who had a sound reading knowledge of a number of classical and oriental languages only knew one vernacular language or dialect. In eighteenthcentury Germany, for instance, relatively few intellectuals knew English, but even more remarkable was the inability of most scholars to read French.

The chronologically ordered contributions in this volume give evidence of this wide variety of applying Latin or vernacular languages, by diverse authors in diverse branches of knowledge, as well as the role of languages in the formation of national identities. The idea that Latin gradually made way for the vernaculars is qualified by the study of Arie Schippers. In his chapter, he shows that the linguistic situation in Italy and Spain was highly complicated. Traditionally, the languages are classified as langue d'oïl (French), langue d'oc (Occitan) and lingua di si (Italian), spoken by French, Spanish troubadours and Italians or Latini respectively. In Italy and Spain a multitude of languages and literatures coexisted together: Latin, used for learned epistles and scientific treatises, epics and other solemn genres, coexisted with several Romance vernaculars, e.g. French for popular prose and Occitan for poetry, and in both countries a literature in classical and vernacular Arabic as well as Classical [= "Biblical"] Hebrew was important as well. Arabic had substituted Latin in

See the contributions to this volume by Floris Cohen and Wiep van Bunge. 
Muslim Spain as an official language. In some Latin and Judeo-Arabic writings we find passages about the coexistence of Latin and Arabic.

The various Romance languages had a variety of literary functions, distributed over the genres. There were French prose works written in Italy, and Italian and Spanish troubadours used the Occitan (Provençal) language in their poems. Some early Italian poet practised Italian poetry as well as Hebrew poetry. Immanuele Romano (1270-1330), alias Manollo Giudeo, enriched the standard Hebrew sonnet years before Petrarch wrote his Italian sonnets for Laura. In Spain, Gallego-Portuguese was used as a poetic language by King Alphonse $\mathrm{x}$ the Wise and his court in the thirteenth century: the same circles used the Castilian language for chancellery prose. Toledo at the time of Alphonse the Wise was not only a centre of troubadour poetry in the Occitan language, but also of Hebrew and Arabic poetry. In addition, it was the place where Arabic and Hebrew scientific works were translated into Latin and Castilian. The situation, Schippers argues, was therefore multilingual rather than bilingual, and the languages existed next to each other, Latin being more in opposition to the vernaculars and the vernaculars interacting.

Desiderius Erasmus of Rotterdam (1466-1536) was a Dutch priest as well as a European humanist. In contrast to many others, he seemed to have used Latin exclusively, ignoring his native language. However, the impact of Dutch or 'Hollands', or German-Alemannic, is an underestimated aspect of his work. ${ }^{23}$ It can be shown that he used-in Latin translation-a fair number of vernacular proverbs and expressions, not only in letters, but also in various works, ranging from his early De contemptu mundi to the more light-hearted Praise of Folly and Lingua, as the late Ari Wesseling points out. Erasmus employs these proverbs as additional evidence or even treats them on a par with ancient wisdom. He also uses them to lend wit and spice to his style. What does this mean in terms of his attitude towards the vernacular? The traditional view needs to be revised. Although he did disdain vernacular languages (out of ignorance and because he revered the bonae litterae), he valued his native language and cherished its proverbial lore. His mother tongue must have had special emotional value for him. The question arises how this preference or inclination relates to his ambivalent attitude towards his fellow countrymen, which is best described in terms of a negative attachment. In fact, the case of Erasmus points to the phenomenon of 'veiled bilingualism'. ${ }^{24}$

23 See also above, n. 20.

24 Bloemendal, 'Veiled Bilingualism and Editing the Erasmi Opera Omnia'. One may also think of Porzio's Latin, which at times reads as Italian in Latin or even as Latinized words. 
Latin and vernacular cultures also meet in the contribution by Arjan van Dixhoorn, who discusses the state of affairs in the Low Countries. The chambers of rhetoric and their performative literary culture that flourished there have long been seen as a peculiar phenomenon of the vernacular popular culture of the Dutch-speaking Low Countries, distinct from and often opposing the neo-Latin humanist culture of the same region. This view has been challenged by literary scholars and historians in the last two decades on the basis of new evidence or new perspectives on existing evidence that show exchange in many ways and on various levels, especially between the Latin-, French-, and Dutch-speaking worlds. It can now be argued that multilingual exchange was essential to the dynamics of the (to a large extent oral) world of the rhetoricians. Van Dixhoorn proposes to focus on the chambers of rhetoric of sixteenth- and early seventeenth-century Antwerp, their performative literary culture, and their leading members, as go-betweens for local vernacular culture and cosmopolitan Latin, French and Dutch culture. To demonstrate this, he analyses networks of leading rhetoricians and scholars and translations as the rhetorical adaptation of texts from other languages. In this contribution, similar processes of transfer, integration and assimilation of literary forms are demonstrated to those described and analysed by Schippers.

Speaking of multilingualism, we should also look at formal aspects of printed works. A substantial number of publications printed during the early modern period contained two or more languages. These books are an eloquent testimony to the polyglot reality of early modern Europe, marked by the coexistence of the overlapping and interactive communities of Latin and the national languages. The said polyglot publications appeared in several genres (emblem books, collections of occasional verse, dictionaries, language courses, translations, etc.), each serving their own distinct purpose. The languages used in these books could also interact in any number of ways, and consequently appeared on the printed page in different formats and different types, reflecting the different status and use of the various languages. Developments in book production ensured that authors and publishers were better able to respond to the editorial challenges posed by the use of different languages in one and the same publication.

Demmy Verbeke analyses a selection of bilingual books in which Latin appears alongside a vernacular language. He discusses what indications the mise-en-page can give us about the function of these bilingual publications, and what they teach us about the status of Latin during the early modern period. In particular, he looks at several bilingual editions of Terence printed in early modern England, and contrasts these examples with a number of other 
bilingual publications in which Latin has a different role and thus appears differently on the printed page.

When we look at the relationship between Latin and the vernacular languages, we usually consider the bonae litterae (belles-lettres, literature). But in the sciences and philosophy Latin and the vernacular were used simultaneously as well. The contribution of Eva del Soldato points to the highly interesting position of cultural egalitarianism or relativism that Aristotle took, assuming that no language is superior to another. By affirming the prevalence of res over verba, Aristotelianism substantially legitimized the practice of translation, or at least this is how the Italian philosopher Sperone Speroni interpreted him in 1542. The famous Neapolitan Aristotelian magister and member of the Accademia Fiorentina, Simone Porzio (1497-1554), is likewise an illustrative case. He favoured the dissemination of philosophical ideas by translations into the vernaculars. After he published a considerable number of Latin books, his companion Giovan Battista Gelli vernacularized-in a sort of instant translation-many of them; he translated his medical books, but 'transferred' them 'culturally', emphasizing in his introductions topics like morality and physiognomy that were secondary in the original works, but more captivating for a larger audience, and some short books about miranda naturae, written for Cosimo's court and admired by it. Latin, however, remained Porzio's preferred means of expression for dense and technical subjects. In the academic world, he used Latin, both in his writings and in his teaching, whereas at court he spoke and wrote the vulgare.

Ingrid Rowland discusses the use of Latin or the vernacular in two works of science, Giordano Bruno's Latin didactic poem De immenso et innummerabilibus ('On the Infinite and Innumerable', 1592) and Galileo Galilei's Dialogo sopra $i$ due massimi sistemi del mondo Tolemaico e Copernicano ('Dialogue on the Two Chief World Systems, of Ptolemy and Copernicus', 1632) in Italian. Whereas Bruno presented his ideas in the traditional form of a didactic poem in Latin, Galilei did so in the scintillating form of a vernacular dialogue, as Plato had done, as Cicero and Seneca had done, and as Bruno himself had done too. What were the reasons for the scientists to choose their form and language? And what is more: what was the role of diagrams in mathematical formulas in their works?

Guillaume van Gemert investigates the relation between Latin and the vernacular in German lands. Van Gemert's first pièce de résistance is Martin Opitz's Aristarchus (1617), an oration he held at the Silesian Academy. In it, he expressed the great German past and pleaded for the use of German-in a speech in Latin. His aim was a political rather than purely literary one: by creating an overall German culture, national identity should be realized as a 
preliminary stage on the road to (ultimately) overcoming the political fragmentation of the German Lands. Seven years later, in his Buch von der deutschen Poeterey (1624), now in German, Opitz expanded upon this approach and fleshed out the detail. He and most of his contemporaries as well as his likeminded followers till the end of the seventeenth century were convinced that the German language could only emancipate into an adequate vehicle for literary activity by referring to and dissociating itself from Latin and Latinbased ancient culture, a process they still regarded as the only way to achieve political unification within the German-speaking countries.

In natural philosophy authors also had to decide-if they were able towhether to write in Latin or in their mother tongue. The criteria on which they made their choices are highly intricate and interesting. Floris Cohen draws some provisional conclusions from his reading of scientific works from the early modern period. He discerns some tendencies in the use of Latin and the vernacular in the sciences. Until 1600 the standard language for mathematics and speculative natural philosophy was Latin, whereas the preferred language for empirical studies was the vernacular. In the seventeenth century, Latin remained the standard for mathematics. For natural history, however, blending theoretical and empirical methods, the choice seems to be arbitrary. Purely experimental natural history tends to use the vernaculars, with the exception of the Jesuit scholars, who wrote in Latin only. The advent of the scientific societies such as the Royal Society strengthened the tendency towards the vernacular. Its journal, the Philosophical Transactions, preferred to report in English, although Latin was allowed too. Perhaps the 'topography' of the natural sciences was an additional factor in the choice, Latin being the language of the universities, the places of speculative science, while the empirical sciences were investigated mainly outside the academic world in the strict sense. Curiously, a few works were a blend of Latin and the vernacular. For instance, Galilei's Discorsi (1638) now and then alternate between Latin and Italian, whereas the Opus Paramirum (1581) by Andreas Vesalius mixed Latin and German. The situation of the choice of language in natural philosophy, therefore, is quite complicated, varying between the methods applied, the period under investigation, and geography. In the Netherlands there was a purist tendency, translating Greek and Latin texts into Dutch terms, or coining new ones.

Wiep van Bunge discusses the use of Latin and the vernaculars in philosophy. He explicitly discerns a difference between academics and non-academics. Philosophy still had a crucial position at the universities, which continued to use Latin as their lingua franca. Even though the vernaculars gradually took the central place of Latin, a philosopher as late as Descartes had to have his 
writings translated into Latin to create an academic following. Kant, as was said before in this introduction, wrote in Latin before turning to German. While it could be argued that the downfall of Latin signalled the rise of a more egalitarian notion of philosophy, enabling a wider audience to participate in the debates to which it gave rise, Kant's creation of a highly specific, technical vocabulary expressing his 'critical', 'transcendental' philosophy hardly contributed to a further proliferation of his insights. Kant's main ambition, rather than to be read by the masses, was to redefine the professional competence of philosophy following the emancipation of the natural sciences. The main issue addressed in Van Bunge's contribution concerns the evolving relationship between the language of early modern philosophy and the way in which it sought to justify its specific expertise as well as its authority.

Françoise Waquet focuses on the eighteenth-century universities, and especially on the languages used in the academic world. The questions she asks include those related to the circumstances in which Latin or one of the vernacular languages was used, what kind of Latin was written and spoken there, and by what reasons members of the academic society themselves explain or justify their choice. There turn out to be multiple reasons, linguistic as well as social, to use Latin and to refuse passage to the vernacular, or to use both languages. It turns out that it was not the quality of Latin that was decisive, but tradition and convenience, the decorum of the University, and the prestige of academic professorships. Waquet takes her examples from Italy, Sweden and France.

Joep Leerssen also engages with Latin in the area of academic learning. He points at the long-lasting use of Latin in this area and at the role of philology and the Latin language in the formation of national identities. Between $175^{\circ}$ and 1850, a development took place which led to a Europe-wide reconceptualization of culture: the philological idea that all cultures are specifically tied to their nationality and their individual (vernacular) language of expression. The rise of the modern philologies alongside the Classics gave expression and an institutional framework to this. Ironically, some key texts in this new national view of culture were couched in the transnational language of learning, Latin. Leerssen argues this resulted in the irony of pleading for the vernacular in Latin. His starting point is Jacob Grimm's already mentioned inaugural lecture at the University of Göttingen, De desiderio patriae (1830).

Bilingual Europe thus offers a broad overview of many aspects of bilingualism and multilingualism in the period between 1300 and 1800 , a decisive period in the formation of Europe, and in the formation of European nation states. As a common ground, Latin provided a language for sciences, cultures and nationalistic feelings, but was gradually replaced by the vernaculars. At 
the same time, Latin and the vernacular languages met and interacted for a far longer period that has been assumed until now, as attested by the studies compiled in this volume. Reciprocal translations were made, vernacular poetry saw its reception in Latin verse, and vice versa. In some instances, the alternatives even competed with each other, both rivaling and cooperating. ${ }^{25}$ The studies brought together in this book accordingly challenge the construction of Latin and the vernaculars as isolated opposites, and the idea that the vernaculars had an overarching influence on the formation of the European nation states. As the reader will notice, the Middle Ages are under-represented, whereas the volume focuses on the second half of the seventeenth and the eighteenth centuries. This is partly due to the state of arts in research on the several periods. It is also a result of the fact that in the eighteenth century there is a gradual and relative shift from Latin to the vernacular: not in all regions, nor in all branches of knowledge at the same time. Moreover, research now tends to focus on this period of change, labelled by Leerssen following Reinhart Koselleck as 'Sattelzeit', a 'saddle' period of transition. Looking at different subjects or different regions, or from different points of view, may now lead to conflicting claims, such as Van Bunge's idea that for philosophy a shift is visible that for the universities in general is not, as Waquet showed; or that there is a Scientific Revolution with a language shift, as Cohen demonstrates; or that one should be careful with the term 'scientific revolution', as proposed by Van Bunge. The change from Latin to the vernacular can be seen as a consequence of the shift from 'bookish' to empiricist knowledge, or as a result of the difference between the international language needed for universities and the usefulness of vernacular language for 'artisanal knowledge'. Many questions still need an answer. Therefore, this volume is also an invitation to carry out further research into the fascinating relationship-whether in opposition, competition or interaction - between Latin and the vernaculars and the questions of at what places, at what times, in what subjects and why Latin was supplanted by the 'modern' languages.

This volume is the result of a conference held on 17-19 September 2009 at the University of Amsterdam, sponsored by the Institute of Culture and History of the faculty of Humanities, and the Huygens Institute for the History of the Netherlands of the Royal Netherlands Academy of Arts and Sciences. It was organized by Joep Leerssen, Juliette A. Groenland and myself, as a conduit for the output of the research group of the Vidi project: 'Latin and Vernacular Cultures: Theatre and Public Opinion in the Netherlands, ca. 1510-1625', funded by the Dutch Organisation of Scientific Research (NWO). I would like to thank

25 See Ford, The Judgment of Palaemon. 
these organizations for their financial support. ${ }^{26}$ Thanks are also due to the anonymous peer reviewers for their valuable remarks. Finally, I would like to thank my colleague Tom Deneire for reading and commenting on a first draft of this introduction. Since Ari Wesseling did not see his article materialize because of his unexpected death on 2 July 2010, I would like to dedicate this volume to his pious memory.

26 Will Kelly of Minerva Professional Language Services (www.minerva-pls.com) corrected the English of this introduction. 